\title{
Analysis of global methane changes after the 1991 Pinatubo volcanic eruption
}

\author{
N. Bândă ${ }^{1,2}$, M. Krol ${ }^{3,4,1}$, M. van Weele ${ }^{2}$, T. van Noije ${ }^{2}$, and T. Röckmann ${ }^{1}$ \\ ${ }^{1}$ Institute for Marine and Atmospheric Research Utrecht, Utrecht University, Utrecht, The Netherlands \\ ${ }^{2}$ Royal Netherlands Meteorological Institute (KNMI), De Bilt, The Netherlands \\ ${ }^{3}$ Dept. of Meteorology and Air Quality, Wageningen University and Research Center, Wageningen, The Netherlands \\ ${ }^{4}$ Netherlands Institute for Space Research (SRON), Utrecht, The Netherlands
}

Correspondence to: N. Bândă (n.1.banda@uu.nl)

Received: 21 June 2012 - Published in Atmos. Chem. Phys. Discuss.: 19 July 2012

Revised: 17 December 2012 - Accepted: 8 February 2013 - Published: 27 February 2013

\begin{abstract}
The global methane $\left(\mathrm{CH}_{4}\right)$ growth rate showed large variations after the eruption of Mount Pinatubo in June 1991. Both sources and sinks of tropospheric $\mathrm{CH}_{4}$ were altered following the eruption, by feedback processes between climate and tropospheric photochemistry. Such processes include Ultra Violet (UV) radiative changes due to the presence of volcanic sulfur dioxide $\left(\mathrm{SO}_{2}\right)$ and sulphate aerosols in the stratosphere, and due to stratospheric ozone depletion. Changes in temperature and water vapour in the following years caused changes in tropospheric chemistry, as well as in natural emissions. We present a sensitivity study that investigates the relative effects that these processes had on tropospheric $\mathrm{CH}_{4}$ concentrations, using a simple onedimensional chemistry model representative for the global tropospheric column. To infer the changes in UV radiative fluxes, the chemistry model is coupled to a radiative transfer model. We find that the overall effect of natural processes after the eruption on the $\mathrm{CH}_{4}$ growth rate is dominated by the reduction in $\mathrm{CH}_{4}$ lifetime due to stratospheric ozone depletion. However, all the other processes are found to have non-negligible effects, and should therefore be taken into account in order to obtain a good estimate of $\mathrm{CH}_{4}$ concentrations after Pinatubo. We find that the overall effect was a small initial increase in the $\mathrm{CH}_{4}$ growth rate after the eruption, followed by a decrease of about $7 \mathrm{ppb} \mathrm{yr}^{-1}$ by mid1993. When changes in anthropogenic emissions are employed according to emission inventories, an additional decrease of about $5 \mathrm{ppb} \mathrm{yr}^{-1}$ in the $\mathrm{CH}_{4}$ growth rate is obtained between the years 1991 and 1993. The results using the simplified single column model are in good qualitative agree-
\end{abstract}

ment with observed changes in the $\mathrm{CH}_{4}$ growth rate. Further analysis, taking into account changes in the dynamics of the atmosphere, variations in emissions from biomass burning, and in biogenic emissions of non-methane volatile organic compounds (NMVOC), requires the use of a full threedimensional model.

\section{Introduction}

$\mathrm{CH}_{4}$ is the second most abundant anthropogenic greenhouse gas in the atmosphere after $\mathrm{CO}_{2}$. Its concentration in the atmosphere has increased since preindustrial times by a factor of 2.5 (Dlugokencky et al., 2011). A good understanding of the processes responsible for variations in the $\mathrm{CH}_{4}$ concentration is needed for making future predictions and developing mitigation strategies. However, the evolution of the $\mathrm{CH}_{4}$ concentrations observed in the background atmosphere in the past three decades is not fully understood (Montzka et al., 2011a). The growth rate of $\mathrm{CH}_{4}$ was generally positive and showed a decreasing trend during the 80s and 90s, with year to year fluctuations (Dlugokencky et al., 2003). As shown in Fig. 7, particularly large fluctuations were observed in the years following the eruption of Mount Pinatubo in 1991 (Dlugokencky et al., 1994, 1996; Bekki and Law, 1997; Butler et al., 2004; Bousquet et al., 2006). After a peak of about $16 \mathrm{ppb} \mathrm{yr}^{-1}$ near the time of the eruption, the globally averaged $\mathrm{CH}_{4}$ growth rate dropped to $-2 \mathrm{ppbyr}^{-1}$ in late 1992, remaining negative for the second half of the year 1992 (Dlugokencky et al., 2003). A subsequent recovery of

Published by Copernicus Publications on behalf of the European Geosciences Union. 
the growth rate to $7 \mathrm{ppbyr}^{-1}$ was observed by the end of 1993.

Changes in the global $\mathrm{CH}_{4}$ concentration are determined by either changes in $\mathrm{CH}_{4}$ emissions or by changes in the $\mathrm{CH}_{4}$ lifetime. $\mathrm{CH}_{4}$ is emitted from both natural sources (e.g. wetlands, oceans and geological seeps) and anthropogenic sources (e.g. agriculture, fossil fuel exploitation, waste treatment and biomass burning). The lifetime of $\mathrm{CH}_{4}$ in the atmosphere is determined by the reaction of $\mathrm{CH}_{4}$ with the hydroxyl radical $(\mathrm{OH})$ in the troposphere, by the uptake of $\mathrm{CH}_{4}$ by soils and by the destruction of $\mathrm{CH}_{4}$ in the stratosphere. The main sink is, however, the reaction with $\mathrm{OH}$, the other processes contributing by only $10-15 \%$ to the $\mathrm{CH}_{4}$ loss (Prather et al., 2001; Spahni et al., 2011). Atmospheric levels of $\mathrm{OH}$ are determined by tropospheric photolysis reactions driven by the incident solar UV radiation, by water vapour levels, and by non-linear tropospheric chemistry. Because $\mathrm{OH}$ reacts with these species, its abundance is sensitive to atmospheric concentrations of $\mathrm{CH}_{4}$, nitrogen oxides $\left(\mathrm{NO}_{\mathrm{x}}\right)$, carbon monoxide (CO) and NMVOC. Montzka et al. (2011b) showed by inversions of methyl chloroform that global tropospheric $\mathrm{OH}$ is relatively stable to perturbations, having an interannual variability of $2.3 \pm 1.5 \%$ for the period 1998 to 2007. Such a small variability was shown to be consistent with the small interannual variability in $\mathrm{CH}_{4}$ concentrations. In a previous study, Prinn et al. (2005) found an interannual variability in tropospheric $\mathrm{OH}$ of 7 to $9 \%$ for the period 1978 to 2004. On a decadal timescale, a possible small positive trend in $\mathrm{OH}$ of the order of $0.2 \% \mathrm{yr}^{-1}$ for the period 1985 to 2000 , and higher after the year 2000, has been suggested by inversions of $\mathrm{CH}_{4}$ and $\delta^{13} \mathrm{C}_{-} \mathrm{CH}_{4}$ (Monteil et al., 2011, scenario P2).

The eruption of Mount Pinatubo triggered a multitude of photochemical effects (McCormick et al., 1995), including feedbacks between climate and atmospheric photochemistry, which contributed to the observed evolution of the $\mathrm{CH}_{4}$ concentrations. The different processes had both positive and negative impacts on the $\mathrm{CH}_{4}$ growth rate, affecting $\mathrm{CH}_{4}$ emissions and the $\mathrm{CH}_{4}$ lifetime. From satellite observations it is estimated that the eruption emitted about $18 \pm 4 \mathrm{Tg} \mathrm{SO}_{2}$ (Guo et al., 2004a). Volcanic $\mathrm{SO}_{2}$ absorbs UV radiation between $290 \mathrm{~nm}$ and $330 \mathrm{~nm}$, thus its presence in the stratosphere would lead to a decrease in ozone photolysis in the troposphere (Dlugokencky et al., 1996). Since OH formation in the troposphere depends on the photolysis of ozone to $\mathrm{O}\left({ }^{1} \mathrm{D}\right)$, the $\mathrm{UV}$ absorption by $\mathrm{SO}_{2}$ would lead to a longer $\mathrm{CH}_{4}$ lifetime. $\mathrm{SO}_{2}$ stayed in the stratosphere for a few months, forming sulphate aerosols with an e-folding time of 23-25 days (Guo et al., 2004a). Enhanced sulphate aerosols were observed by the SAGE II satellite instrument for up to $4 \mathrm{yr}$ after the eruption at heights between 15 and $30 \mathrm{~km}$ with a maximum globally averaged aerosol optical depth (AOD) at $550 \mathrm{~nm}$ of approximately $\tau=0.15$ about 7 months after the eruption (Russell et al., 1996; Thomason et al., 1997). Scattering of solar radiation by sulphate aerosols would lead to a further reduction of photolysis frequencies in the troposphere, thus to a longer $\mathrm{CH}_{4}$ lifetime. Particles of ash emitted directly by the eruption would also absorb and scatter solar radiation, determining a similar effect on $\mathrm{CH}_{4}$ lifetime. However, because of their lifetime of only a few days, they are considered to have a negligible global impact (Guo et al., 2004b; Niemeier et al., 2009) and are not included in our study.

Another secondary effect on the $\mathrm{CH}_{4}$ lifetime is triggered by the destruction of stratospheric ozone on sulphate aerosols. A maximum global ozone depletion of $5 \%$ was observed by TOMS about two years after the eruption (Chipperfield et al., 2003). Changes of similar magnitude have been obtained in modelling studies (Kinnison et al., 1994; Bekki and Pyle, 1994), and were attributed to enhanced heterogeneous ozone-depleting reactions on sulphate aerosols and changes in circulation due to stratospheric aerosol heating. Stratospheric ozone loss would lead to an increase of UV radiation in the troposphere, and thus to a higher $\mathrm{OH}$ abundance and a shorter $\mathrm{CH}_{4}$ lifetime.

The eventual fate of the volcanic sulfur is deposition to the surface. The modelling results of Gauci et al. (2008) indicate that deposition of $122 \mathrm{Tg} \mathrm{SO}$ emitted by the Laki eruption led to a decrease of $8.8 \mathrm{Tg} \mathrm{yr}^{-1}$ in $\mathrm{CH}_{4}$ emissions from wetlands in the two years following the eruption. As a rough estimate assuming linearity, the Pinatubo eruption would lead to $1.3 \mathrm{Tg}$ decrease in the emissions. We consider this effect to be small and do not investigate it further here.

Other effects of the eruption on $\mathrm{CH}_{4}$ concentrations have occurred because of temperature changes after the eruption (Bekki and Law, 1997). The scattering of shortwave radiation by aerosols led to an increase in the reflected solar radiation of up to $10 \mathrm{~W} \mathrm{~m}^{-2}$ at the top of the atmosphere (Bender et al., 2010). This affected tropospheric temperatures, leading to an observed global cooling of up to $0.45 \mathrm{~K}$ in the two years following the eruption (Free and Angell, 2002). Bender et al. (2010) show that ten general circulation models give a maximum decrease of $0.5 \mathrm{~K}$ in response to the observed changes in the shortwave radiative flux after the eruption. They attribute the $0.05 \mathrm{~K}$ difference between models and observations to the coinciding El Niño event.

Temperature perturbations trigger changes in the chemical composition of the atmosphere, as well as in natural sources related to biogenic activity. A decrease in temperature would generally slow down photochemical transformations. In particular, the slowdown of the reaction between $\mathrm{CH}_{4}$ and $\mathrm{OH}$ would lead to higher tropospheric $\mathrm{CH}_{4}$ concentrations (Bekki and Law, 1997). Soden et al. (2002) found that the cooling after the eruption is associated to a maximum global decrease of $3 \%$ in the water vapour column in both observations and model simulations. Less water vapour in the troposphere would imply less $\mathrm{OH}$ formation by photolysis of ozone, because the reaction between $\mathrm{O}\left({ }^{1} \mathrm{D}\right)$ and water becomes less likely. This would increase the $\mathrm{CH}_{4}$ lifetime, leading to $\mathrm{CH}_{4}$ build-up in the atmosphere. 
Natural emissions from wetlands, accounting for about $30 \%$ of the total emissions in the year 2004 (Spahni et al., 2011), are sensitive to temperature and soil moisture changes. Furthermore, natural emissions of NMVOC are known to be temperature dependent (Guenther et al., 1993). A decrease in the surface temperature would result in reductions in both $\mathrm{CH}_{4}$ emissions from wetlands and biogenic NMVOC emissions. Biogenic emissions of NMVOC are also dependent on the amount of photosynthetically active radiation (PAR) reaching the surface (Guenther et al., 1993). Decrease in PAR fluxes because of enhanced aerosol scattering would further decrease these emissions. While a reduction in $\mathrm{CH}_{4}$ emissions directly impacts $\mathrm{CH}_{4}$ concentrations, a decrease in NMVOC emissions may affect $\mathrm{OH}$, and thus impose an indirect impact on the $\mathrm{CH}_{4}$ lifetime.

The eruption of Pinatubo also changed the dynamics of the atmosphere, which might have influenced $\mathrm{OH}$ and $\mathrm{CH}_{4}$ concentrations. It was inferred in the 4-box modelling study of Schauffler and Daniel (1994) that heating of the stratosphere may increase the exchange between the stratosphere and the troposphere, leading to a decrease in tropospheric $\mathrm{CH}_{4}$ concentrations. Lowe et al. (1997) suggest that a large effect of enhanced stratosphere-troposphere exchange would be inconsistent with the decrease in observed $\delta^{13} \mathrm{C}$ in this period. However, other isotope data from this period do not support a strong decrease in $\delta^{13} \mathrm{C}$ between 1991 and 1992 (Quay et al., 1999).

Although the processes presented above are known to have contributed to the evolution of the $\mathrm{CH}_{4}$ growth rate after the Pinatubo eruption, their relative magnitudes are not yet totally resolved. $\mathrm{CH}_{4}$ observations show the net outcome of these processes and other processes not related to the eruption, such as changes in anthropogenic emissions. The growth rate changes after the eruption have been attributed in other studies to changes in either sources or sinks. Dlugokencky et al. (1996) show that the evolution of $\mathrm{CH}_{4}$ and CO in 1991 and early 1992 is consistent with a decrease in $\mathrm{OH}$ for up to one year after the eruption. They relate this decrease in $\mathrm{OH}$ to an attenuation of the UV flux due to the presence of $\mathrm{SO}_{2}$ and sulphate in the stratosphere. Additionally, Dlugokencky et al. (1994) relate the decrease in $\mathrm{CH}_{4}$ growth rate in 1992 to a decrease in anthropogenic emissions due to the collapse of the Soviet Union. The modelling study of Bekki and Law (1997) shows that temperature-related effects had a significant impact on the growth rate of $\mathrm{CH}_{4}$ in 1991-1992. They find that reduced emissions from wetlands may partly or fully explain the reduced growth rate in 1992 . The inverse modelling study of Butler et al. (2004) reveals a global source-sink imbalance of $+27 \mathrm{Tg} \mathrm{CH}_{4}$ for the year 1991 and $-19 \mathrm{Tg}$ for the year 1992. In their inverse modelling studies, Bousquet et al. (2006) and Wang et al. (2004) both find a decrease in wetland emissions of $20-25 \mathrm{Tg}$ between 1991 and 1993. Bousquet et al. (2006) also find reductions in the biomass burning and anthropogenic emissions, as well as in the $\mathrm{OH}$ sink for this period. In contrast, Wang et al.
(2004) postulate an increase in $\mathrm{OH}$ due to reduced stratospheric ozone. Using a two-dimensional model, Bekki et al. (1994) also conclude that half of the $\mathrm{CH}_{4}$ growth rate reduction in 1992 can be attributed to the effect of decreased stratospheric ozone. In the modelling study of Telford et al. (2010) it is found that natural isoprene emissions have a minimum in early 1993, yielding an increase in the $\mathrm{CH}_{4}$ sink of $5 \mathrm{Tg} \mathrm{yr}^{-1}$. Telford et al. (2010) also show that variations in meteorology lead to a decrease in the $\mathrm{CH}_{4}$ sink of up to $14 \mathrm{Tg} \mathrm{yr}^{-1}$, mainly due to changes in temperature and water vapour following the eruption. To our knowledge, no complete study has been made to include all competing effects of the Pinatubo eruption and to analyse the processes responsible for $\mathrm{OH}$ and $\mathrm{CH}_{4}$ growth rate variations. Quantifying these processes may help us gain a better understanding of the $\mathrm{CH}_{4}$ budget and, consequently, to make better predictions of the future atmospheric burdens.

In this sensitivity study we will use a simplified tropospheric column chemistry model as a first step to assess the changes in the $\mathrm{CH}_{4}$ growth rate after the Pinatubo eruption and the relative contributions of the various processes. First, we will analyse how the equilibrium state of the chemical system changes when varying individual conditions (emissions, photolysis frequencies, water vapor). The impact on the tropospheric steady state gives us an idea about the drivers of $\mathrm{CH}_{4}$ and $\mathrm{OH}$ concentrations, and about the relative magnitude of different processes. Next, we allow the system to respond to transient perturbations. The response of $\mathrm{CH}_{4}$ concentrations to natural changes after the eruption will be contrasted to their response to changes in anthropogenic emissions. Due to obvious limitations of a single column model, the effect of changes in the dynamics of the atmosphere cannot be studied here. Additionally, because of the high sensitivity of $\mathrm{OH}$ to isoprene emissions in our model (see Sect. 3.1.1), we do not include the effect of changes in NMVOC emissions.

A detailed description of the column chemistry model is presented in Sect. 2. In Sect. 3.1 we show sensitivities of the model, and evaluate its performance in representing the global atmosphere in the period 1890-2005. We show our results on steady-state and transient $\mathrm{CH}_{4}$ changes after Pinatubo in Sect. 3.2, and conclusions are drawn in Sect. 4.

\section{Model setup}

The model used in this study is a one-dimensional column chemistry model, coupled to the radiation model TUV (Madronich (1993), http://cprm.acd.ucar.edu/Models/TUV/). The chemistry model can be used both in steady-state and transient versions. The effects of atmospheric perturbations on photolysis frequencies are calculated with the radiative transfer model TUV, and then employed in the chemistry model. 
Table 1. Reactions included in the model. Reaction rate coefficients are the ones described in Huijnen et al. (2010), except for photolysis rates, which are computed using TUV.

\begin{tabular}{|c|c|}
\hline Reactants & Products \\
\hline $\mathrm{O}_{3}+h v$ & $2 \times \mathrm{OH}$ \\
\hline $\mathrm{NO}_{2}+h v$ & $\mathrm{O}_{3}+\mathrm{NO}$ \\
\hline $\mathrm{O}_{3}+\mathrm{NO}$ & $\mathrm{NO}_{2}$ \\
\hline $\mathrm{O}_{3}+\mathrm{OH}$ & $\mathrm{HO}_{2}$ \\
\hline $\begin{array}{l}\mathrm{O}_{3}+\mathrm{HO}_{2} \\
\mathrm{HO}_{2}+\mathrm{HO}_{2}\end{array}$ & $\mathrm{OH}$ \\
\hline $\mathrm{HO}_{2}+\mathrm{OH}$ & \\
\hline $\begin{array}{l}\mathrm{HO}_{2}+\mathrm{NO} \\
\mathrm{NO}_{2}+\mathrm{OH}\end{array}$ & $\mathrm{OH}+\mathrm{NO}_{2}$ \\
\hline $\mathrm{CO}+\mathrm{OH}$ & $\mathrm{HO}_{2}$ \\
\hline $\mathrm{CH}_{4}+\mathrm{OH}$ & $0.9 \times \mathrm{CO}+\mathrm{RO}_{2}$ \\
\hline $\mathrm{RH}+\mathrm{OH}$ & $0.35 \times \mathrm{CO}+\mathrm{RO}_{2}$ \\
\hline $\mathrm{RO}_{2}+\mathrm{NO}$ & $\mathrm{NO}_{2}+y \times \mathrm{HO}_{2}$ \\
\hline $\mathrm{RO}_{2}+\mathrm{HO}_{2}$ & \\
\hline $\mathrm{RO}_{2}+\mathrm{RO}_{2}$ & \\
\hline
\end{tabular}

\subsection{The column chemistry model}

In this exploratory study we use a strongly simplified model that represents the troposphere in 10 vertical layers of $1.5 \mathrm{~km}$ thickness each. The chemical scheme employs 8 chemical species, of which 5 are transported between adjacent layers $\left(\mathrm{O}_{3}, \mathrm{NO}_{\mathrm{x}}, \mathrm{CH}_{4}, \mathrm{CO}, \mathrm{RH}\right) . \mathrm{OH}, \mathrm{HO}_{2}$ and $\mathrm{RO}_{2}$ are not transported, but calculated in steady state with the longer-lived transported species. Here $\mathrm{RH}$ stands for NMVOC, and $\mathrm{RO}_{2}$ for peroxy-radicals formed from NMVOC and $\mathrm{CH}_{4}$ oxidation.

Vertical transport is defined by vertical diffusion coefficients of $10 \mathrm{~m}^{2} \mathrm{~s}^{-1}$ between the first two layers (at $1.5 \mathrm{~km}$ ), $5 \mathrm{~m}^{2} \mathrm{~s}^{-1}$ between the second and 3rd layers (at $3 \mathrm{~km}$ ) and $2 \mathrm{~m}^{2} \mathrm{~s}^{-1}$ higher up. No flux to the stratosphere is considered except for ozone and $\mathrm{CH}_{4}$. For ozone, we fix the concentration in the upper layer (at $13.5 \mathrm{~km}$ ) at $148 \mathrm{ppb}$. A flux of $40 \mathrm{Tg} \mathrm{yr}^{-1}$ to the stratosphere is considered for $\mathrm{CH}_{4}$, following Prather et al. (2001).

The chemical reactions included are presented in Table 1. We run the model with all-day all-year averaged reaction rate coefficients and photolysis frequencies. The $0.9 \mathrm{CO}$ yield from $\mathrm{CH}_{4}$ oxidation is comparable to that found by complex 3-D global chemistry models (Shindell et al., 2006). The yield of CO from the oxidation of NMVOC varies strongly between species (Grant et al., 2010). We use here a global $\mathrm{CO}$ yield from NMVOC of $0.35 . \mathrm{CH}_{4}$ oxidation produces $\mathrm{CH}_{3} \mathrm{O}_{2}$, which may react with $\mathrm{NO}$, yielding at least one molecule of $\mathrm{HO}_{2}$ through all the reaction pathways. $\mathrm{CH}_{3} \mathrm{O}_{2}$ is included in the model as $\mathrm{RO}_{2}$, together with other compounds produced from NMVOC oxidation. Thus we consider an $\mathrm{HO}_{2}$ yield $y$ from the reaction of $\mathrm{RO}_{2}$ and $\mathrm{NO}$, equal to the ratio between the $\mathrm{CH}_{3} \mathrm{O}_{2}$ production from $\mathrm{CH}_{4}$ and the total
$\mathrm{RO}_{2}$ production. For computational reasons, we use a global yield determined from a steady-state assumption. The rate of production of $\mathrm{CH}_{3} \mathrm{O}_{2}$ from $\mathrm{CH}_{4}$ oxidation is equal to the rate of loss of $\mathrm{CH}_{4}$ in this reaction. Assuming steady state, this is equal to the emission rate of $\mathrm{CH}_{4}\left(E_{\mathrm{CH}_{4}}\right)$. Similarly, the rate of $\mathrm{RO}_{2}$ production from NMVOC is equal to the emission rate of NMVOC $\left(E_{\mathrm{RH}}\right)$. Therefore the $\mathrm{HO}_{2}$ yield $y$ from the reaction of $\mathrm{RO}_{2}$ and $\mathrm{NO}$ is taken as $\frac{E_{\mathrm{CH}_{4}}}{E_{\mathrm{CH}_{4}}+E_{\mathrm{RH}}}$.

Dry deposition of ozone and $\mathrm{NO}_{2}$ are included with a deposition velocity of $1.0 \times 10^{-3} \mathrm{~m} \mathrm{~s}^{-1}$. An additional loss of $\mathrm{NO}_{2}$ through heterogeneous reactions is considered, with a deposition velocity of $1.5 \times 10^{-4} \mathrm{~m} \mathrm{~s}^{-1}$ throughout the column.

A time-dependent version of the chemistry model performs transient simulations using the Euler Backward Iterative scheme with a time step of one hour.

\subsection{Photolysis frequencies}

The TUV model version 4.1 is used to calculate the effects of $\mathrm{SO}_{2}$, aerosols and ozone column on tropospheric photolysis frequencies. Yearly averaged photolysis frequencies are calculated by averaging daily mean photolysis frequencies at $30^{\circ} \mathrm{N}$ for the 15 th of the months of March, June, September and December. This latitude band is used because photochemistry is most active in the tropics, and is chosen such that $\mathrm{CH}_{4}$ concentrations and lifetime are realistically reproduced.

For the base scenario, the climatological aerosol profile of Elterman (1968) is used, with an aerosol single scattering albedo of 0.99 .

\subsection{Emissions and atmospheric parameters}

Global anthropogenic emissions for $\mathrm{NO}_{\mathrm{x}}, \mathrm{CO}, \mathrm{CH}_{4}$ and NMVOCs are taken from EDGAR 4.1 yearly values for the years 1970-2005 (European Commission and Joint Research Centre (JRC)/Netherlands Environmental Assessment Agency (PBL), 2010), and EDGAR-HYDE decadal emissions for the years 1890-1970 (Van Aardenne et al., 2001). Natural emissions used are described in Huijnen et al. (2010), except for $\mathrm{CH}_{4}$ emissions, which are taken from Spahni et al. (2011) posterior values for the year 2004. The evolution of $\mathrm{CH}_{4}$ emissions implemented in the model is shown in Fig. 4. In addition to surface $\mathrm{NO}_{\mathrm{x}}$ emissions, we add yearly $6.3 \mathrm{Tg} \mathrm{N}$ of $\mathrm{NO}_{\mathrm{x}}$ from lightning (Huijnen et al., 2010), evenly distributed throughout the column in terms of mixing ratios.

Profiles of temperature, water vapour, ozone, and air density for $30^{\circ} \mathrm{N}$ were derived from the global 3-D chemistry transport model TM5 (Huijnen et al., 2010) driven by ERAInterim meteorological fields (Dee et al., 2011) for the year 2005. These are applied both in TUV and in the column chemistry model. The ozone columns for the four months used here are respectively 302, 294, 283 and 270 Dobson Units (DU). 
Table 2. Setup of the Pinatubo simulations. AOD = aerosol optical depth; DU = Dobson Unit.

\begin{tabular}{lll}
\hline Simulation name & Changes implemented in TUV & Changes implemented in the column chemistry model \\
\hline $\mathrm{SO}_{2}$ & $2.54 \mathrm{DU}$ of $\mathrm{SO}_{2}$ between 15 and $30 \mathrm{~km}$ altitude & Changes in photolysis frequencies from TUV \\
Aerosol & $0.15 \mathrm{AOD}$ due to Pinatubo between 15 and $30 \mathrm{~km}$ altitude & Changes in photolysis frequencies from TUV \\
Ozone & $5 \%$ ozone column decrease & Changes in photolysis frequencies from TUV \\
Temp Rates & & Changed reaction rate coefficients due to temperature \\
$\mathrm{H}_{2} \mathrm{O}$ & & Changes in water vapour profile due to changed temperature profile \\
$\mathrm{CH}_{4}$ Emis & & Changes in $\mathrm{CH}_{4}$ emissions from wetlands due to temperature \\
$\mathrm{Temp} \mathrm{All}$ & & Changes in reaction rate coefficients, water vapour and $\mathrm{CH}_{4}$ \\
& & emissions due to temperature
\end{tabular}
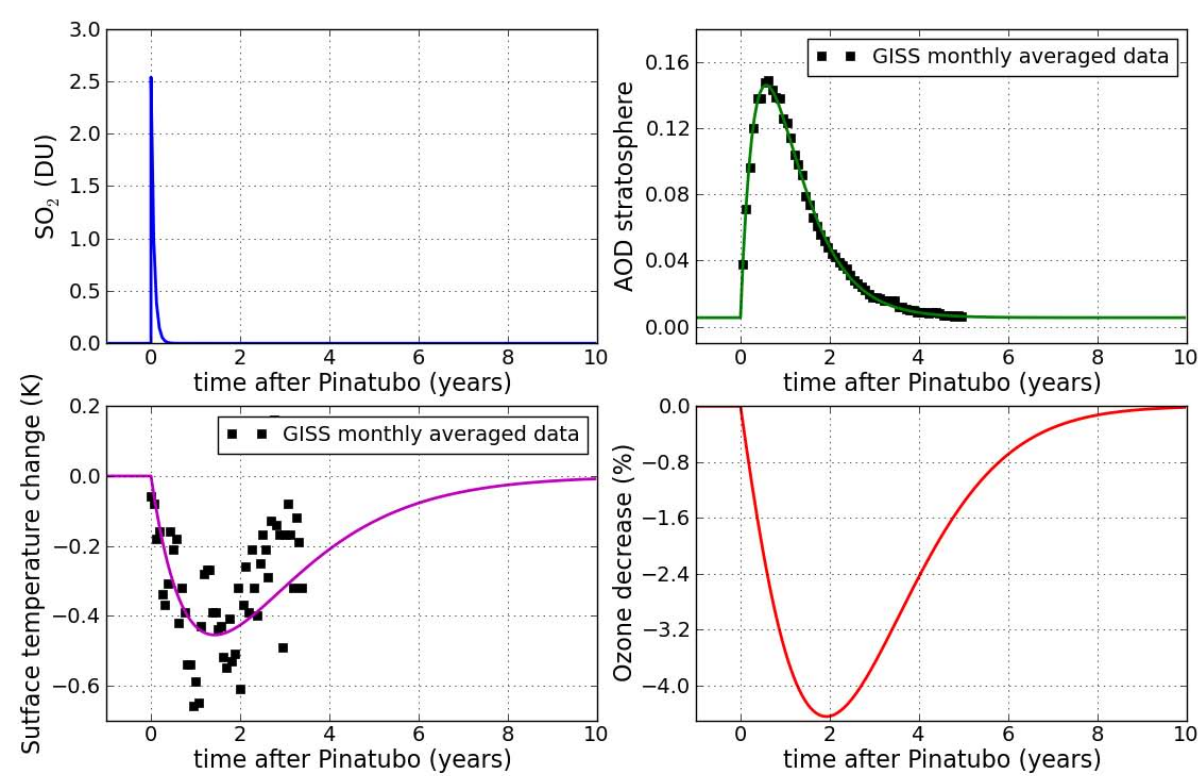

Fig. 1. Time evolution of the forcings, as implemented in the model. Squares represent monthly averaged GISS data (Hansen et al., 2005, 2010).

\subsection{Implementation of Pinatubo perturbations}

We define two sets of simulations. First, we evaluate the change in the model state due to individual natural perturbations after the eruption, in order to distinguish the most important drivers of $\mathrm{CH}_{4}$ concentrations. In the second set of simulations we also include variations in anthropogenic $\mathrm{CH}_{4}$ sources, with the aim to reproduce the evolution of the global $\mathrm{CH}_{4}$ concentration in the early 1990s.

In the first set of simulations, we define the base simulation as the 1990 equilibrium situation. Next, the change in the model state due to the natural perturbations after Pinatubo is evaluated as a steady-state and as a transient response. The perturbations implemented in TUV and the column chemistry model are summarised in Table 2 . In these sensitivity experiments, we assume constant anthropogenic and biomass burning emissions.
To compute the perturbations in photolysis frequencies after Pinatubo in TUV, we implement single forcings of $5 \%$ decrease in ozone column, $2.54 \mathrm{DU}$ increase in $\mathrm{SO}_{2}$, equivalent to $18.5 \mathrm{Tg} \mathrm{SO}_{2}$, and 0.15 increase in AOD. $\mathrm{SO}_{2}$ and aerosols are considered to be evenly distributed in our atmospheric column between 15 and $30 \mathrm{~km}$ altitude. In the column chemistry model, the perturbations in photolysis frequencies are then scaled with the magnitudes of the forcings, thus assuming that the effects of these processes are linear. In addition, we assume additivity between the different processes by adding the perturbations in photolysis frequencies when more than one process is considered. We tested the effect of this assumption on our results by performing two simulations: one in which we used photolysis rates calculated with TUV by implementing all the forcings at the same time, and one in which we implemented each forcing separately and assumed additivity. The difference in the $\mathrm{CH}_{4}$ steady-state concentration between the two simulations is $0.5 \mathrm{ppb}$, which is small compared to the magnitude of the perturbations related to the eruption. 
The time evolution of the forcings assumed in the column chemistry model is based on observed values, and is shown in Fig. 1. For $\mathrm{SO}_{2}$, an exponential decay with an e-folding time of 24 days is considered, as found by Guo et al. (2004a), and a starting global mean concentration of $2.54 \mathrm{DU}$ directly after the eruption. For the aerosol optical thickness, we use the Goddard Institute for Space Studies (GISS) monthly averaged values (Hansen et al., 2005), based on SAGE II satellite data. Surface temperature is taken from GISS analysis data (Hansen et al., 2010). The global mean GISS data for AOD and temperature are interpolated in the 4.5 and $3.5 \mathrm{yr}$ following the eruption, respectively. The resulting evolutions have a peak at approximately 7 and 15 months after the eruption, respectively, and then a smooth decay, which is extrapolated for $10 \mathrm{yr}$. To a $0.5 \mathrm{~K}$ temperature decrease at the surface, we associate a tropospheric temperature change of $0.5 \mathrm{~K}$ decrease below $214.4 \mathrm{hPa}$, and a $1 \mathrm{~K}$ increase at $87.7 \mathrm{hPa}$, following the observations from Free and Angell (2002), and interpolate between these values. These profile changes are then scaled with the magnitude of the surface temperature change. For ozone decrease, we use an evolution that has a peak of $4.5 \% 2 \mathrm{yr}$ after the eruption and then decays to 0 , following the results of Randel et al. (1995).

The water vapour profile as a function of temperature change is evaluated using the Clausius-Clapeyron equation, assuming constant relative humidity. Variations in emissions of $\mathrm{CH}_{4}$ from wetlands due to temperature are calculated using the $\mathrm{Q}_{10}$ temperature dependence relation (Dunfield et al., 1993), with a $Q_{10}$ value of 2 . For a temperature decrease of $0.5 \mathrm{~K}$, we find that $\mathrm{CH}_{4}$ wetland emissions decrease from $171.8 \mathrm{Tg} \mathrm{yr}^{-1}$ to $165.9 \mathrm{Tg} \mathrm{yr}^{-1}$.

The second set contains two additional transient simulations, which enable us to compare the magnitude of natural effects after the eruption to that of variations in anthropogenic sources. In both simulations we employ yearly anthropogenic emissions from EDGAR 4.1, while keeping the biomass burning emissions constant at 1990 values. In the first simulation, natural emissions and atmospheric parameters are kept constant. In the second one we also include the natural forcings after the eruption. These simulations are performed starting from the steady state in the year 1890, using EDGAR-HYDE and EDGAR 4.1 emissions for the spin-up period between 1890 and 1990.

\subsection{Methyl chloroform model}

For validating the transient $\mathrm{OH}$ concentrations obtained with our column chemistry model, we perform an offline simulation of methyl chloroform (MCF) for the period 1988 to 2005 . We use the same column model, with only one chemical tracer, MCF.

The MCF emissions used are the same as described in Montzka et al. (2011b). The main sink of MCF is the reaction with $\mathrm{OH}$ in the troposphere. We use $\mathrm{OH}$ fields from each time step of the transient simulation for the period 1890 to 2005
Table 3. Yearly emissions for 1890 and 1990 implemented in the model. Emission units are given in parentheses.

\begin{tabular}{|c|c|c|}
\hline Species (unit) & 1890 & 1990 \\
\hline $\mathrm{CH}_{4}\left(\mathrm{Tg} \mathrm{yr}^{-1}\right)$ & 278 & 512 \\
\hline $\left.\mathrm{Nyr}^{-1}\right)$ & 22.7 & 47.6 \\
\hline $\mathrm{CO}\left(\operatorname{Tg~yr}^{-1}\right)$ & 460 & 1177 \\
\hline NMVOC $\left(\mathrm{Tg} \mathrm{Cyr}^{-1}\right)$ & 707 & 808 \\
\hline
\end{tabular}

(the first simulation of the second set), and a temperaturedependent reaction rate as given in JPL 2011 (Sander et al., 2011). Additional stratospheric and ocean sinks are considered with lifetimes of 38 and $80 \mathrm{yr}$, respectively. These are in the range of values found by Krol and Lelieveld (2003).

We use an initial condition in 1988 of 115 ppt throughout the column.

\section{Results and discussion}

\subsection{Model evaluation}

Even though the model presented above contains many simplifications, we will show that it performs reasonably well in representing the global state of the troposphere.

Figure 2 presents the steady-state profiles for $\mathrm{CH}_{4}, \mathrm{O}_{3}$, $\mathrm{NO}_{\mathrm{x}}$, and $\mathrm{CO}$ obtained by the column chemistry model for the years 1890 and 1990 . The yearly emission values used are shown in Table $3 . \mathrm{CH}_{4}$ decreases with altitude by about $100 \mathrm{ppb}$ throughout the troposphere in the year 1990. CO mixing ratios for the same year decrease with altitude from $125 \mathrm{ppb}$ at the surface to $30 \mathrm{ppb}$ near the tropopause. The $\mathrm{NO}_{\mathrm{x}}$ profile has the typical C-shape due to the production of $\mathrm{NO}_{\mathrm{x}}$ by lightning throughout the column and the longer lifetime of $\mathrm{NO}_{\mathrm{x}}$ in the upper troposphere. Ozone mixing ratios decrease with altitude in the first few kilometers, and then increase towards the stratosphere.

Between the years 1890 and 1990, we find increases in ozone, $\mathrm{CO}$ and $\mathrm{CH}_{4}$, which are more pronounced near the surface due to increases in emissions of ozone precursors, $\mathrm{CO}$ and $\mathrm{CH}_{4}$. For $\mathrm{NO}_{\mathrm{x}}$ we find increases both near the surface, because of increased emissions, as well as near the tropopause, due to an increase in the $\mathrm{NO}_{\mathrm{x}}$ lifetime at this altitude. This is consistent with a decrease in $\mathrm{OH}$ in the upper troposphere due to higher $\mathrm{CH}_{4}$ concentrations. In the study of Wang and Jacob (1998), zonal averaged profiles for ozone, $\mathrm{OH}, \mathrm{NO}_{\mathrm{x}}$ and $\mathrm{CO}$ are computed using a threedimensional model of tropospheric chemistry for preindustrial and year 1990 conditions. Concentrations of ozone and $\mathrm{NO}_{\mathrm{x}}$ near the surface are somewhat higher in our model, possibly due to the fact that no differentiation is made between land and ocean in our simplified single column model. Our model finds a higher $\mathrm{CO}$ variability throughout the column, which may be caused by the fact that we did not 

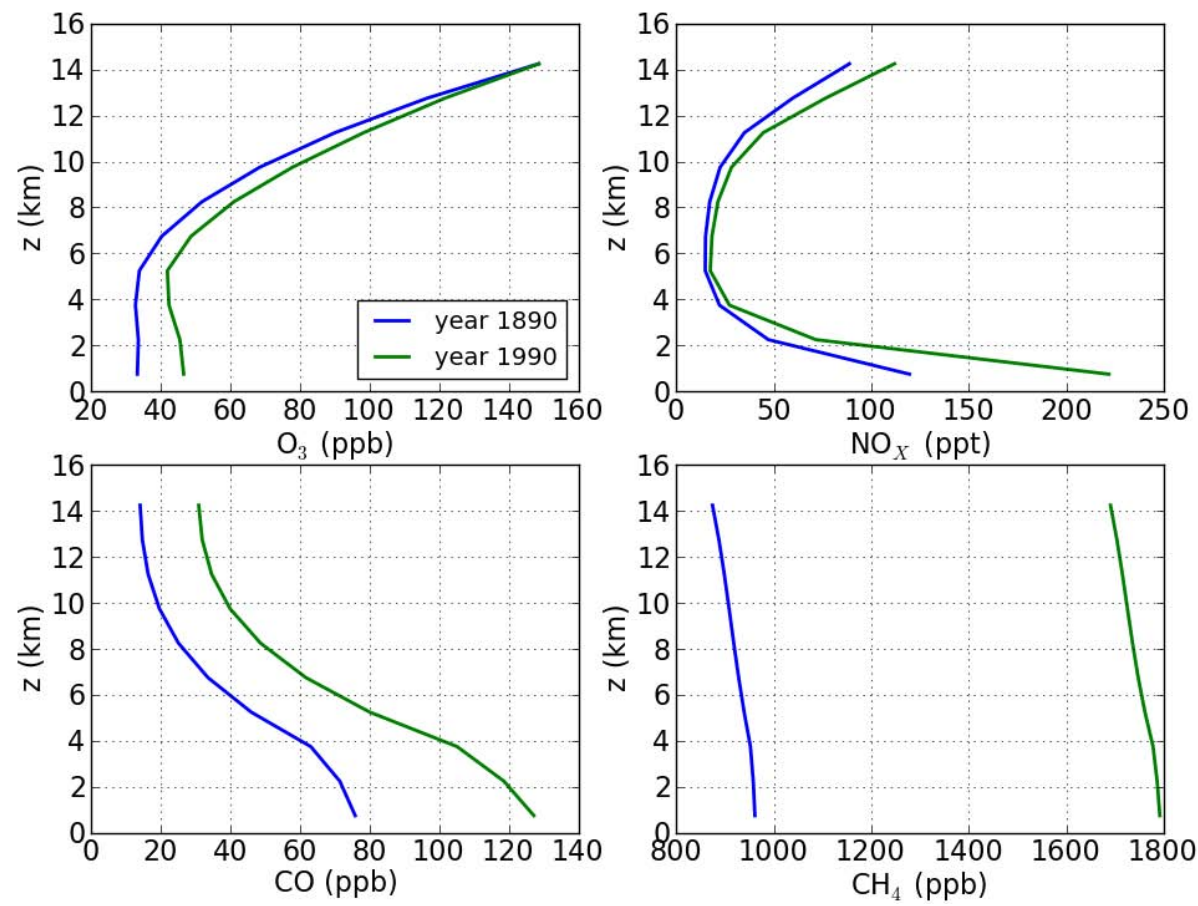

Fig. 2. Vertical profiles of ozone, $\mathrm{NO}_{\mathrm{x}}, \mathrm{CO}$, and $\mathrm{CH}_{4}$ obtained with the one dimensional model for the years 1890 and 1990 .

Table 4. Comparison of trace gas budgets for the global troposphere obtained with our one-dimensional model, with the results from other

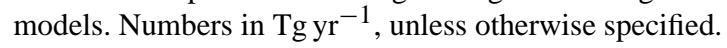

\begin{tabular}{lcccc}
\hline & $\begin{array}{c}\text { Stevenson et al. (2006), } \\
\text { S1 scenario }\end{array}$ & $\begin{array}{c}\text { Shindell et } \\
\text { al. (2006) }\end{array}$ & $\begin{array}{c}\text { Williams et } \\
\text { al. (2012) }\end{array}$ & $\begin{array}{c}\text { One-dimensional } \\
\text { model }\end{array}$ \\
\hline Ozone chemical production & $5110 \pm 606$ & & 4729 & 6117 \\
Ozone chemical loss & $4668 \pm 727$ & & & 5009 \\
Ozone deposition & $1003 \pm 200$ & & 863 & 1349 \\
Ozone stratospheric exchange & $552 \pm 168$ & & 274 & 241 \\
Ozone burden (Tg) & $344 \pm 39$ & & 320 & 448 \\
Ozone lifetime (days) & $22.3 \pm 2$ & $11.3 \pm 1.7$ & 23.4 & 25.7 \\
OH (molec cm ${ }^{-3}$ ) & & & 1663 & 9.5 \\
OH production from photolysis & & $1505 \pm 236$ & 3522 & 2061 \\
OH chemical production & & & 3214 & 3519 \\
CO chemical production & & & 48.3 & 360 \\
CO burden (Tg) & & $9.7 \pm 1.7$ & 8.35 & 52.1 \\
CO lifetime (days) & & & 8.2 \\
CH lifetime (yrs) & $8.76 \pm 1.32$ & & & \\
\hline
\end{tabular}

formulate a convective redistribution of the column. In terms of changes in concentrations between the preindustrial setup and the year 1990, our model finds generally lower relative changes than the study of Wang and $\mathrm{Jacob}$ for $\mathrm{O}_{3}, \mathrm{NO}_{\mathrm{x}}$ and $\mathrm{CO}$, possibly due to the different emission sets that are used. However, the $30 \%$ increase in $\mathrm{OH}$ that we find in the lowest $1.5 \mathrm{~km}$ of the model, and about $20 \%$ decrease between 6 and $12 \mathrm{~km}$ altitude compare well with their study.

In Table 4, we compare the ozone, $\mathrm{OH}$ and $\mathrm{CO}$ budgets given by our model for the year 1990 to global budgets found by several 3-dimensional chemistry transport models presented in Williams et al. (2012); Stevenson et al. (2006); Shindell et al. (2006). Overall, our model falls within the uncertainties of these models in terms of $\mathrm{OH}$ and $\mathrm{CO}$ burdens and budgets. $\mathrm{CO}$ and $\mathrm{CH}_{4}$ lifetimes are also modeled realistically, certainly when one considers the huge simplifications of the chemical system and the simplified representation of the global atmosphere. Ozone burden, production, and deposition are high compared to full 3-D models. These are more representative of tropical values than global ones, likely due 
to the choice of tropical conditions to represent the global troposphere. For the same reason, ozone stratospheric inflow is quite low. This is because most ozone inflow occurs in the extratropics (Gettelman et al., 2011), while our model column is in the tropics.

\subsubsection{Model sensitivities}

We further evaluate the sensitivity of the model to parameters involved in this study, i.e. to $\mathrm{CH}_{4}$ and isoprene emissions, ozone column, temperature and water vapour (Table 5). We compare the sensitivities of our model to sensitivities of 2-D and 3-D models present in literature. Except for the sensitivity to $\mathrm{CH}_{4}$ emissions, these studies evaluate other sensitivities while keeping $\mathrm{CH}_{4}$ concentrations fixed, or by looking at timescales of a few years. Because of the $\mathrm{CH}_{4}$ lifetime of about $8 \mathrm{yr}$, the feedback of $\mathrm{CH}_{4}$ concentrations on its own lifetime is ineffective on such a short period. Therefore we also calculate these sensitivities while keeping $\mathrm{CH}_{4}$ concentrations fixed.

The effect of $\mathrm{CH}_{4}$ emission changes on the $\mathrm{CH}_{4}$ concentrations is enhanced by the feedback via the $\mathrm{CH}_{4}$ lifetime. To describe this process, a feedback factor $a$ is defined as $a=1 /\left(1-\frac{d \ln \tau}{d \ln \mathrm{CH}_{4}}\right)$, following Voulgarakis et al. (2012). Here $\tau$ stands for the $\mathrm{CH}_{4}$ lifetime, and the small offsets $d \ln \mathrm{CH}_{4}$ and $d \ln \tau$ are determined by a small perturbation in $\mathrm{CH}_{4}$ emissions. We find that $a$ has a value of 1.45 for the year 1990, which compares well with the best estimate of the Third Assessment Report of the IPCC (Prather et al., 2001), and falls well in the range found in the model intercomparison study of Voulgarakis et al. (2012).

Another sensitivity that is important to our study is the sensitivity of $\mathrm{CH}_{4}$ to changes in the ozone column. In the two-dimensional modelling study of Bekki and Pyle (1994), a $6 \%$ increase in $\mathrm{OH}$ is found due to a $6 \%$ decrease in stratospheric ozone between the years 1991 and 1993 . We find that a $6 \%$ decrease in ozone column leads to a $6.4 \%$ enhancement in $\mathrm{OH}$, which compares well to their results. Other studies that assess the sensitivity of $\mathrm{CH}_{4}$ and $\mathrm{OH}$ to ozone column changes find lower sensitivities (Camp et al., 2001; Fuglestvedt et al., 1994). However, the ozone perturbations in these studies are dominated by the middle and high latitudes, where ozone photolysis and $\mathrm{CH}_{4}$ oxidation are less important. After the Pinatubo eruption, both low and high latitude ozone columns were affected (Chipperfield et al., 2003). Therefore we consider it more appropriate to compare our results to Bekki and Pyle (1994).

To test the sensitivity of our model to climate, we used a temperature increase of $1 \mathrm{~K}$ throughout the column, and computed the corresponding change in humidity using the Clausius-Clapeyron equation. The $\mathrm{CH}_{4}$ lifetime change of $-0.49 \mathrm{yr} \mathrm{K}^{-1}$ in our model is somewhat larger than the multimodel mean of $-0.31 \pm 0.14 \mathrm{yr} \mathrm{K}^{-1}$ found in Voulgarakis et al. (2012). However, we do not include changes in stratospheric ozone related to temperature. We use observed

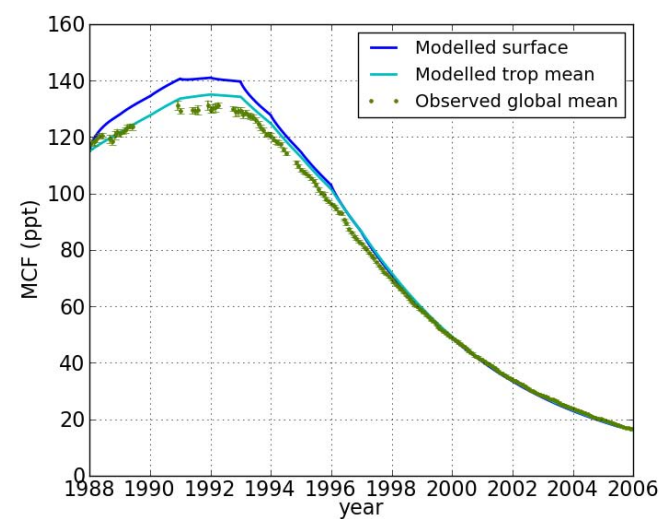

Fig. 3. Observed and modeled evolution of methyl chloroform surface and tropospheric mean mixing ratios between 1988 and 2006.

changes in stratospheric ozone, and the effect of temperature on ozone concentrations is included in the observations. The two models used in Voulgarakis et al. (2012) that also do not include this feedback give higher sensitivities to temperature, of -0.4 and $-0.57 \mathrm{yr} \mathrm{K}^{-1}$. Therefore we consider our model to respond to temperature changes in a similar manner as global chemistry models.

Telford et al. (2010) found a maximum decrease in isoprene emissions of $9 \%$ due to lower temperature and lower PAR fluxes in the year 1992 due to the presence of aerosols in the stratosphere. They find a corresponding $1 \%$ increase in $\mathrm{OH}$ tropospheric burden. We test the sensitivity of our model to such a perturbation in isoprene emissions, and find that our model is two times more sensitive. We attribute this again to our one-column approach, in which we cannot account for horizontal transport. Isoprene reacts rapidly with $\mathrm{OH}$, and regions with large and small isoprene emissions are present in the true atmosphere. Furthermore, our simplified chemistry scheme is not well suited to explore the sensitivity to changing NMVOC emissions. A more recent study shows that the effect of aerosols on isoprene emissions is smaller if diffuse and direct radiation is treated separately (Wilton et al., 2011). We conclude therefore that the calculated feedback of NMVOC emissions on $\mathrm{OH}$ is highly uncertain, and we decide not to include it in further simulations. We simply note that decreases (increases) in NMVOC emissions probably lead to more (less) $\mathrm{OH}$ and a shorter (higher) $\mathrm{CH}_{4}$ lifetime.

\subsubsection{Evaluation of $\mathrm{CH}_{4}$ and methyl chloroform concentrations}

The results on MCF surface and tropospheric mean mixing ratios are shown in Fig. 3. We compare our simulation results to the observations-based global mean mixing ratios, computed by averaging the GAGE/AGAGE data at the stations Mace Head, California, Barbados, Samoa, and Cape Grim. 
Table 5. Sensitivities and feedback factors of our column chemistry model and comparison to literature.

\begin{tabular}{|c|c|c|c|}
\hline Sensitivity & 1-D model & Value in literature & Study \\
\hline $\begin{array}{l}\text { Feedback factor between } \mathrm{CH}_{4} \text { emissions and } \mathrm{CH}_{4} \\
\text { concentrations }\end{array}$ & 1.45 & $\begin{array}{l}1.4 \\
1.23-1.69\end{array}$ & $\begin{array}{l}\text { IPCC TAR, Prather et al. (2001) } \\
\text { Voulgarakis et al. (2012) }\end{array}$ \\
\hline $\begin{array}{l}\text { Change in tropospheric } \mathrm{OH} \text { due to a } 6 \% \text { increase } \\
\text { in ozone column }(\%)\end{array}$ & 6.4 & 6 & Bekki and Pyle (1994) \\
\hline $\begin{array}{l}\text { Change in } \mathrm{CH}_{4} \text { lifetime due to a } 1 \mathrm{~K} \text { increase in } \\
\text { global temperature }\left(\mathrm{yr} \mathrm{K}^{-1}\right)\end{array}$ & -0.49 & $-0.31 \pm 0.14$ & Voulgarakis et al. (2012) \\
\hline $\begin{array}{l}\text { Change in tropospheric } \mathrm{OH} \text { due to a } 9 \% \text { decrease } \\
\text { in isoprene emissions }(\%)\end{array}$ & 1.9 & 1. & Telford et al. (2010) \\
\hline
\end{tabular}

The modelled total lifetime of MCF is $4.6 \mathrm{yr}$ and the lifetime with respect to $\mathrm{OH}$ is $5.7 \mathrm{yr}$, in agreement with other studies (Krol and Lelieveld, 2003; Prinn et al., 2005). When we sample the model at the surface in the period in which MCF emissions were significant (1988-1998), the model is seen to overestimate the observed mixing ratios. This is related to differences in the sampling of the model and the observations. Observations are generally taken in remote areas, away from the emissions, in order to be representative for the global burden. In our one-dimensional model, the sampling is done in the surface grid box, where the emissions are also put in. Therefore a tropospheric mean sampling of the model is in better correspondence with the observations. This is confirmed by the fact that our modelled tropospheric mean MCF mixing ratios are in very good agreement with GAGE/AGAGE observations. A tropospheric mean sampling of the model will be used in the rest of the paper.

The results for $\mathrm{CH}_{4}$ concentrations from the first simulation of the second set, as defined in Sect. 2.4, are shown in Fig. 4. They are compared to global means for the period 1890 to 1990 , calculated from ice core measurements in Etheridge et al. (1998). Following the same procedure as used in Etheridge et al. (1998), we estimate global mean mixing ratios for the period 1985 to 2005 based on the monthly means from the GLOBALVIEW-CH4 (2009) data from the stations Alert and South Pole. The global mean is therefore computed as the mixing ratio at South Pole plus $37 \%$ of the interpolar difference. Modelled $\mathrm{CH}_{4}$ mixing ratios generally follow the decadal trends in $\mathrm{CH}_{4}$ emissions, with a delay of about $10 \mathrm{yr}$ due to the $\mathrm{CH}_{4}$ lifetime. The stabilization of the concentrations towards the end of the simulation period is a phenomenon that is also present in the observations (Dlugokencky et al., 2003).

Compared to the observations, our model follows quite well the trends in $\mathrm{CH}_{4}$ mixing ratios, but generally overestimates $\mathrm{CH}_{4}$ mixing ratios by up to $50 \mathrm{ppb}$. We expect this to happen in the first decades of the simulation, because the starting point represents a steady state, while the system might not have been in equilibrium in the year 1890 . The concentration continues to be overestimated until 1990, pointing either to an overestimation of the $\mathrm{CH}_{4}$ emissions

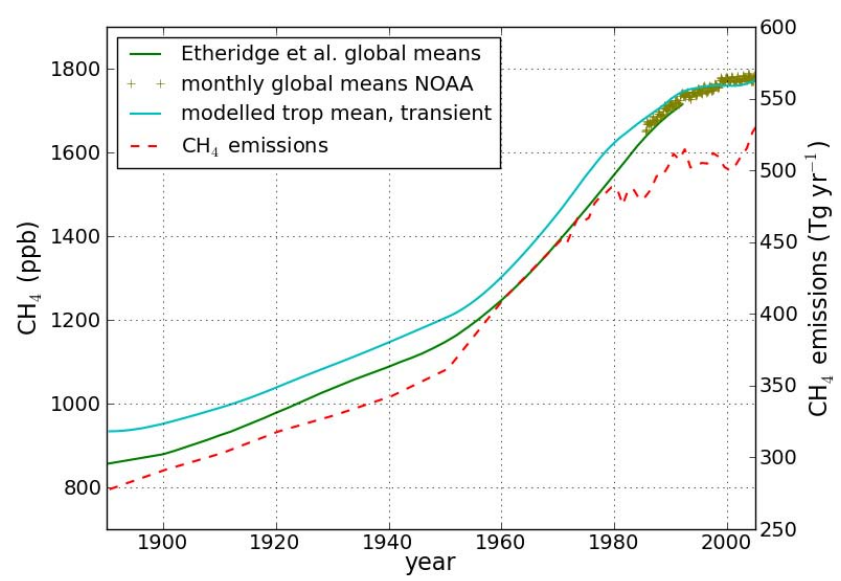

Fig. 4. Observed and modeled evolution of $\mathrm{CH}_{4}$ mixing ratios between 1890 and 2005. Observation-based global means are calculated by Etheridge et al. (1998) based on ice-core data (green line), and more recent global means are calculated using measurements at South Pole and Alert NOAA stations (green crosses). $\mathrm{CH}_{4}$ emissions implemented in the model are also shown (red dotted line, with scale on the right axis) (Van Aardenne et al., 2001; Spahni et al., 2011).

or of the $\mathrm{CH}_{4}$ lifetime in this period. These results are only based on changing anthropogenic emissions $\left(\mathrm{NO}_{\mathrm{x}}, \mathrm{CO}, \mathrm{CH}_{4}\right.$, NMVOC) for the simulated period, and there are several possible explanations for the differences between modelled and observed concentrations. Firstly, processes not included here, such as changes in stratospheric ozone, temperatures and possible trends in natural and biomass burning emissions can have a significant impact on $\mathrm{CH}_{4}$ concentrations. Secondly, we are not able to represent high and low $\mathrm{NO}_{\mathrm{x}}$ regions in our column chemistry model. For this reason, our model might misrepresent the sensitivity of $\mathrm{CH}_{4}$ concentrations to $\mathrm{NO}_{\mathrm{x}}$ and NMVOC emissions. Finally, we use a fixed $\mathrm{CO}$ yield from NMVOC oxidation for the simulated period. This yield varies among species and among $\mathrm{NO}_{\mathrm{x}}$ pollution environments, therefore we would expect it to change on a centennial scale. However, the chosen model setup captures the observed range of $\mathrm{CH}_{4}$ concentrations in the period 1990-2005, which is the period we are interested in. 

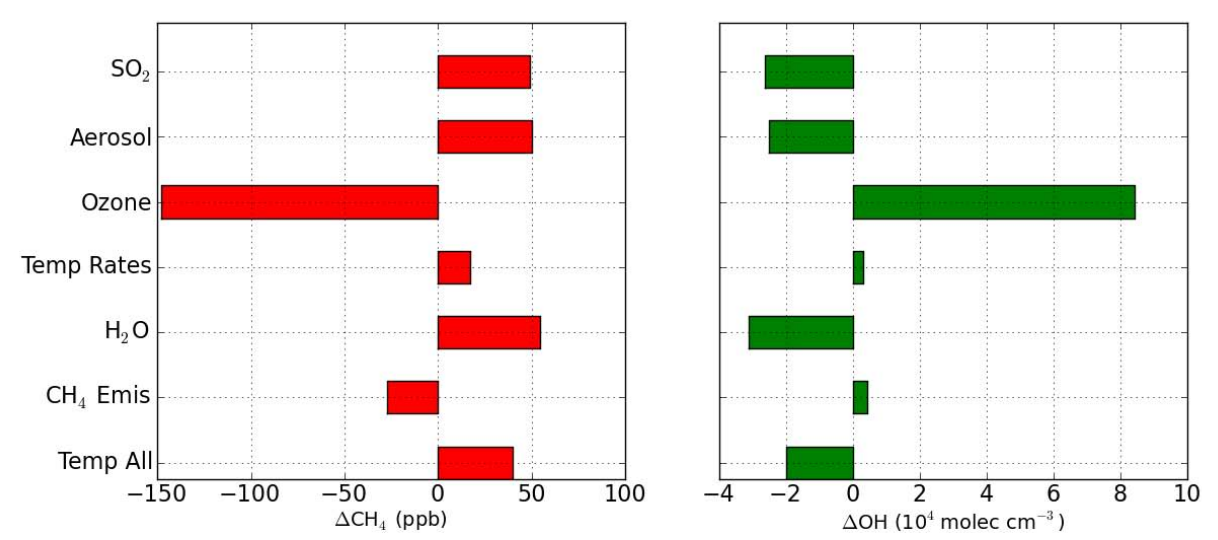

Fig. 5. $\mathrm{CH}_{4}$ and $\mathrm{OH}$ steady-state changes due to various Pinatubo forcings.

We conclude that our model properly represents the global budgets and lifetimes of the different species, and is able to reproduce the mean state of the atmosphere in the 1990s. The sensitivities relevant for this study are reasonably represented. However, the model is too simplified to capture variations of $\mathrm{CH}_{4}$ on a centennial scale, or vertical profiles of different species present in the model. Our sensitivity tests also show that the sensitivity of the model to NMVOC emissions is overestimated.

\subsection{The Pinatubo eruption}

\subsubsection{Steady-state perturbations}

We first examine the effect of each of the forcings of the Pinatubo eruption described in Table 2 on the $\mathrm{CH}_{4}$ equilibrium concentration, using the maximum magnitude of each forcing. The differences in tropospheric $\mathrm{CH}_{4}$ and $\mathrm{OH}$ between each simulation and the "base" simulation are shown in Fig. 5.

We find that the $5 \%$ reduction in ozone column has the largest effect on the tropospheric mean $\mathrm{CH}_{4}$ equilibrium mixing ratio, decreasing it by $125 \mathrm{ppb}$. $\mathrm{SO}_{2}$, aerosol and water vapour changes all increase the $\mathrm{CH}_{4}$ steady-state by 48 to $55 \mathrm{ppb}$. The effects of temperature decrease on $\mathrm{CH}_{4}$ emissions and reaction rates have smaller impacts on the simulated steady-state mixing ratios, of 27 and $17 \mathrm{ppb}$ respectively. The temperature-related processes, that is "Temp Rates", " $\mathrm{H}_{2} \mathrm{O}$ " and " $\mathrm{CH}_{4}$ Emis", partly cancel each other, resulting in an overall increase of $40 \mathrm{ppb}$.

Except for the effects of changed $\mathrm{CH}_{4}$ emissions and changed reaction rates, the effects on $\mathrm{CH}_{4}$ are strongly correlated to effects on $\mathrm{OH}$ of the same relative magnitude and of opposite sign. The $\mathrm{OH}$ response to decreasing $\mathrm{CH}_{4}$ emissions reflects the effectiveness of the feedback factor introduced in the previous section. Changed reaction rates due to tropospheric cooling lead to a small increase in $\mathrm{OH}$, because of the slower oxidation rate of $\mathrm{CH}_{4}$.

\subsubsection{Evolution of transient concentrations and growth rate}

The modelled transient evolution of $\mathrm{CH}_{4}$ mixing ratios due to individual natural perturbations following the eruption, and including their overall effect, are shown in Fig. 6a. When all natural effects are included, the tropospheric mean $\mathrm{CH}_{4}$ mixing ratio slightly increases for 9 months after the eruption. Afterwards it decreases, reaching a maximum decrease of $13 \mathrm{ppb}$ about $6 \mathrm{yr}$ after the eruption. The magnitudes of the perturbations in transient concentrations are smaller than the effects on the steady states, occurring at different moments in time after the eruption and on different timescales. Because the $\mathrm{CH}_{4}$ lifetime is about $8 \mathrm{yr}$, the concentration at one moment in time shows an integrated effect of its sourcesink imbalance in the previous years. Therefore not only the magnitude, but also the duration of the perturbation plays an important role in determining its effect on $\mathrm{CH}_{4}$ concentrations. The recovery time to the initial concentration is much longer compared to the recovery time of the perturbations applied. The $\mathrm{SO}_{2}$ effect is hardly observed in the transient concentrations, because of its short duration. All the other processes affect the $\mathrm{CH}_{4}$ concentration for up to $40 \mathrm{yr}$ after the eruption.

We calculate the $\mathrm{CH}_{4}$ growth rate by differentiating the transient mixing ratios. The overall effect of the natural forcings after Pinatubo on the tropospheric $\mathrm{CH}_{4}$ growth rate (Fig. 6b) is a positive jump of $3 \mathrm{ppb} \mathrm{yr}^{-1}$ due to UV absorption by $\mathrm{SO}_{2}$ immediately after the eruption. The effect decreases, but remains positive for about 9 months after the eruption, due to the presence of $\mathrm{SO}_{2}$ and sulphate aerosols in the stratosphere. After that, the effect on the $\mathrm{CH}_{4}$ growth rate is dominated by the forcing exerted by ozone depletion, partly counteracted by decreased water vapour. The overall effect of natural forcings on $\mathrm{CH}_{4}$ growth rate experiences a minimum of $-5 \mathrm{ppb} \mathrm{yr}^{-1}$ about $2 \mathrm{yr}$ after the eruption. The growth rate increases afterwards, reaching zero about $6 \mathrm{yr}$ after the eruption, when the effect on the transient $\mathrm{CH}_{4}$ mixing ratios is at a minimum (Fig. 6a). The slow recovery of the 

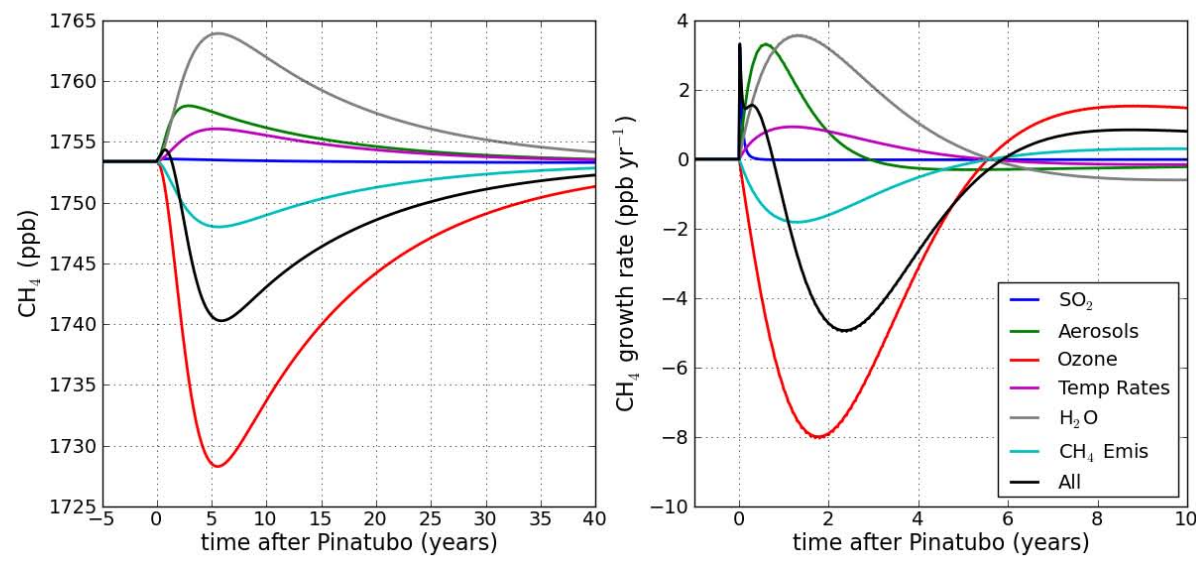

Fig. 6. Effect of the different Pinatubo forcings on the temporal evolution of the tropospheric mean $\mathrm{CH}_{4}$ mixing ratio and growth rate.

concentrations to the steady state is marked by a small positive growth rate of less than $1 \mathrm{ppbyr}^{-1}$. The shape of the growth rate evolution reflects the annual imbalance between $\mathrm{CH}_{4}$ sources and sinks.

We find a positive $\mathrm{CH}_{4}$ growth rate for about 9 months after the eruption. The effect of temperature on the reaction rates is small in this period, and the temperature effect on emissions leads to a negative growth rate. Therefore we can only relate this positive growth rate to a decrease in $\mathrm{OH}$, as also suggested by Dlugokencky et al. (1996). The large effect of ozone depletion which follows compares well with the results of Bekki et al. (1994). They report a $7 \mathrm{ppb} \mathrm{yr}^{-1}$ decrease in growth rate from spring 1991 to autumn 1992 due to ozone depletion. The drop in $\mathrm{CH}_{4}$ growth rate due to ozone depletion in our model is associated with a $5 \%$ increase in $\mathrm{OH}$. This is consistent with the findings of Wang et al. (2004) of a global drop in $\mathrm{OH}$ of $10^{5} \mathrm{molec} \mathrm{cm}^{-3}$, equivalent to 7\%, between the end of 1991 and beginning of 1994. Using the same parametric model, but keeping stratospheric ozone constant, they find much smaller variability in $\mathrm{OH}$ in this period, on the order of 1-2\%. Similar to our results, Bousquet et al. (2006) find an increase in the $\mathrm{OH}$ sink until the beginning of 1992, and then a subsequent decrease in 1992 and 1993. However, they find different magnitudes of these changes compared to our study, leading to an overall increase in the OH sink between 1991 and 1993. The magnitude of the temperature-related effects that we find compares well with the estimate from in Bekki and Law (1997). We find a maximum of $6 \mathrm{Tg} \mathrm{yr}^{-1}$ change in wetland emissions after the eruption. This is similar to the bottom up estimate of about $5 \mathrm{Tg} \mathrm{yr}^{-1}$ shown in Spahni et al. (2011) Fig. 8a, but a few times lower than the maximum anomaly of about $40 \mathrm{Tg} \mathrm{yr}^{-1}$ found in the inverse modelling study of Bousquet et al. (2006). Our lower estimate might be partly due to the fact that we considered changes in $\mathrm{CH}_{4}$ emissions solely due to temperature. $\mathrm{CH}_{4}$ emissions also depend on spatial and temporal changes in soil moisture and precipitation, which have been observed after the eruption (Spahni et al., 2011).
Changes in wetland extent were also shown to have a large impact on the interannual variability in $\mathrm{CH}_{4}$ emissions from wetlands (Ringeval et al., 2010), which is also not taken into account in the study of Spahni et al. (2011) for the years 1991 and 1992. In addition, we consider a global $\mathrm{Q}_{10}$ factor of 2 , while this factor was shown to be dependent on ecosystem type, with a range of measured values between 1.6 and 16 (Dunfield et al., 1993; Valentine et al., 1994).

The results show that stratospheric ozone changes had a large impact on $\mathrm{CH}_{4}$ growth rate after the eruption. The WMO 2003 report (Chipperfield et al., 2003) shows that the total ozone in the atmosphere decreased between the years 1991 and 1993 by about 5\%. Similar numbers are found when excluding the high latitudes (for $60^{\circ} \mathrm{S}-60^{\circ} \mathrm{N}$ ), or when looking only at the tropical region $\left(25^{\circ} \mathrm{S}-25^{\circ} \mathrm{N}\right)$. This change was caused partly by natural variability, including an increase in the solar activity in this period, and partly by processes related to the eruption. Therefore, after removing the effects of the solar cycle and QBO, a decrease of $2 \%$ to $3 \%$ is found in the measured total ozone between 1991 and $1993 . \mathrm{CH}_{4}$ measurements are affected by changes in the ozone column, irrespective of their cause. For this reason, we used here a maximum decrease of $4.5 \%$ in the ozone column, representative for $60^{\circ} \mathrm{S}-60^{\circ} \mathrm{N}$, which includes solar variability. To distinguish the change in $\mathrm{CH}_{4}$ concentrations due to changes in ozone related to the eruption, a smaller perturbation should be considered.

The modelled $\mathrm{CH}_{4}$ growth rate from the second set of simulations, when varying anthropogenic emissions of $\mathrm{CH}_{4}$, $\mathrm{CO}, \mathrm{NO}_{\mathrm{x}}$ and NMVOC, is shown in Fig. 7. These simulations have a starting point in 1890 , producing a more realistic growth rate at the moment of the eruption of $10 \mathrm{ppb} \mathrm{yr}^{-1}$. Results for the full length of the simulation, without including the post-Pinatubo perturbations, are shown in Fig. 4. We compare our results with the observationsbased global mean growth rate, obtained by globally averaging the $\mathrm{CH}_{4}$ reference marine boundary layer matrix from GLOBALVIEW-CH4 (2009), and deseazonalising it using 


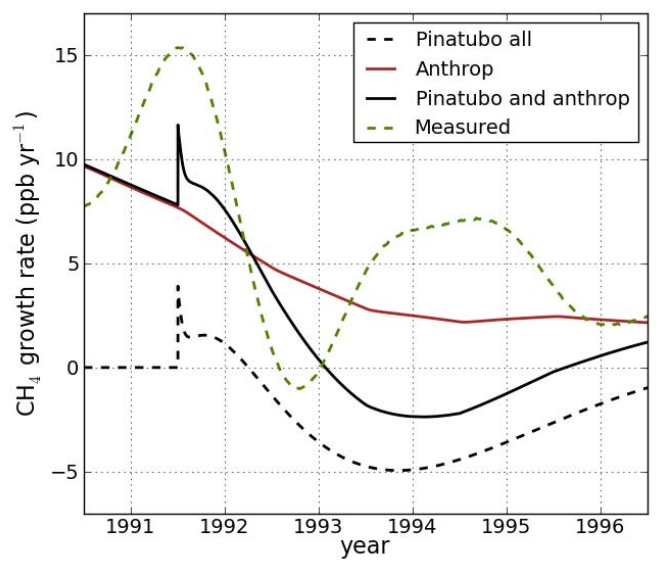

Fig. 7. Modelled growth rate evolution after the Pinatubo eruption including variations due to anthropogenic emissions, and the combined signal from natural and anthropogenic changes. The black dotted line shows the growth rate evolution obtained in the first set of simulations, including all natural forcings (the same as the black line in Fig. 6b). Also shown is the measured globally averaged growth rate obtained using the reference marine boundary layer matrix from GLOBALVIEW-CH4 (2009).

the software provided by NOAA (based on Thoning and Tans (1989)). $\mathrm{CH}_{4}$ anthropogenic emissions were relatively stable in the years 1990 to 2000, while anthropogenic $\mathrm{NO}_{\mathrm{x}}$ emissions increased and $\mathrm{CO}$ emissions decreased. Therefore we find a generally decreasing trend in $\mathrm{CH}_{4}$ growth rate due to a decrease in $\mathrm{CH}_{4}$ lifetime, when only variations in anthropogenic emissions are taken into account.

When both variations in anthropogenic emissions and natural forcings are included in the model, a similar range of values is found for the modelled and observed growth rates in the years 1991 to 1996 . These values vary between more than $10 \mathrm{ppb} \mathrm{yr}^{-1}$ and slightly negative values of up to $-2 \mathrm{ppb} \mathrm{yr}^{-1}$. Decreased anthropogenic $\mathrm{CH}_{4}$ emissions between the years 1991 and 1993 are found to contribute by an additional $5 \mathrm{ppbyr}^{-1}$ to the drop in $\mathrm{CH}_{4}$ growth rate in this period, in agreement with previous studies (Dlugokencky et al., 1994; Bousquet et al., 2006). The timing of the minimum growth rate after the eruption is modelled about 15 months later than that observed. This minimum is found by a complex balance between the different forcings, being later than the minimum in any of the individual forcings applied. Therefore the discrepancy between the timing of the modelled minimum and of the observed one might be related to the simplified evolution of the temperature and ozone changes applied, or the fact that some sources of variability (see below) are not taken into account. This might also explain the fact that the increased growth rate in 1994 is not captured in our simplified simulations.
By comparing the sum of the "Pinatubo all" and "Anthrop" curves to the growth rate evolution when including both Pinatubo forcings and changes in anthropogenic emissions, we find that the effect of nonlinearity on growth rates is less than $10 \%$.

Since our study is an idealised sensitivity study, there are many possible reasons for differences between the modelled and the observed growth rate. Firstly, many processes known to determine $\mathrm{CH}_{4}$ variability are not included here. These include changes in biomass burning emissions (Bousquet et al., 2006), isoprene emissions (Telford et al., 2010) and variability in wetland emissions due to atmospheric changes related to the El Niño Southern Oscillation (ENSO) cycle (Hodson et al., 2011). Secondly, differences may result from the different sampling of the model and the observations, as already mentioned in Sect. 3.1.2. The interpolation procedure used to obtain the observed global $\mathrm{CH}_{4}$ growth rate curve can also smoothen out some sudden variations in the $\mathrm{CH}_{4}$ growth rate, such as the jump due to the $\mathrm{SO}_{2}$ injected by the eruption. Finally, there are uncertainties related to our model setup, on which we elaborate further below.

In order to show that our results are robust with respect to the parameters used in the model, a series of sensitivity tests was performed. We tested different temperature and water vapour profiles, a higher value for the $\mathrm{CO}$ yield from the oxidation of NMVOC, including NMVOC recycling, and increased vertical mixing. Although the effect on the modelled $\mathrm{CH}_{4}$ concentrations in the last century may be on the order of $100 \mathrm{ppb}$ (results not shown), the effect on the growth rate evolution after the eruption is less than $10 \%$. Changing the temperature by $-2.5 \mathrm{~K}$ to $+1 \mathrm{~K}$ and simultaneously changing the water vapour profile according to the ClausiusClapeyron equation lead to changes in the $\mathrm{CH}_{4}$ growth rate results of less than $0.1 \mathrm{ppb} \mathrm{yr}^{-1}$. Similar results are obtained when changing the $\mathrm{CO}$ yield from NMVOC to 0.5 instead of 0.35 , or when doubling the vertical mixing coefficients. Including a 0.25 yield of $\mathrm{HO}_{2}$ from the oxidation of NMVOC in the presence of $\mathrm{NO}_{\mathrm{x}}$ leads to a higher growth rate mini-

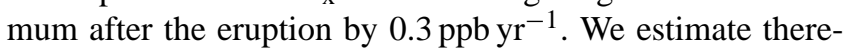
fore a maximum error of $10 \%$ in the modelled growth rate due to uncertainties in the model parameters.

Horizontal distributions of the modelled forcings can play an important role for the overall effect on the $\mathrm{CH}_{4}$ growth rate, and cannot be simulated in our column model. This may cause additional uncertainties in our results. For example, we expect to overestimate the effect of $\mathrm{SO}_{2}$, by inferring an instant homogenisation of the emissions. In reality, high concentrations were found close to the emission point after the eruption, and the short lifetime of $\mathrm{SO}_{2}$ limited this effect to low latitudes (Guo et al., 2004a). Changes in stratospheric aerosol, ozone and temperature have been observed globally, but with different magnitudes at different latitudes. Since $\mathrm{CH}_{4}$ oxidation is more important in the tropics, processes that are relatively stronger in the tropics will have a higher impact on the $\mathrm{CH}_{4}$ lifetime. 


\section{Conclusions}

We have implemented a column chemistry model, and tested its performance in representing the mean state of the atmosphere. Although we acknowledge that our model is simplified and difficult to apply in a globally-averaged fashion, it allowed us to quantify for the first time the combined effect of radiation and temperature-related effects after the Pinatubo eruption on the $\mathrm{CH}_{4}$ growth rate, including feedbacks on the $\mathrm{CH}_{4}$ lifetime. The results show that full recovery of transient $\mathrm{CH}_{4}$ concentrations from these perturbations takes about $40 \mathrm{yr}$.

Using this simple approach, we are able to explain a large part of the observed drop in $\mathrm{CH}_{4}$ growth rate after the eruption of Pinatubo. We conclude that a multitude of emission and lifetime effects contributed to the observed growth rate variations following the eruption, as has been suggested by previous inverse modelling studies (Bousquet et al., 2006; Wang et al., 2004). We find that about $7 \mathrm{ppb} \mathrm{yr}^{-1}$ of the observed $17 \mathrm{ppbyr}^{-1}$ can be explained by natural processes after the eruption. The dominating effects operate through tropospheric photolysis rates, with an important contribution from ozone depletion. This shows the importance of stratospheric-tropospheric couplings, and that a good representation of stratospheric chemistry is needed in order to model accurately $\mathrm{CH}_{4}$ concentrations. We also find that the decrease in anthropogenic emissions between 1991 and 1993 contributed by $5 \mathrm{ppb} \mathrm{yr}^{-1}$ to the decreased $\mathrm{CH}_{4}$ growth rate in 1993. The remaining $5 \mathrm{ppbyr}^{-1}$ of the observed drop in $\mathrm{CH}_{4}$ growth rate remains unexplained, and might be related to changes in emissions from biomass burning or changes in biogenic NMVOC emissions.

Our model has the advantage of simplicity; however, there are processes that cannot be represented, such as horizontal transport and changes in the dynamics of the atmosphere. Additionally, we did not consider the spatial distribution of $\mathrm{CH}_{4}$ emissions. Using a global vegetation model would allow better estimates of the response of natural emissions to changes in temperature, precipitation and radiation. Therefore, a three dimensional chemistry transport model coupled with a climate model will be used to perform future experiments.

Acknowledgements. This work was supported by the Netherlands Organisation for Scientific Research (NWO) and the EU FP7 Integrated Project PEGASOS. We thank the NOAA global air sampling network for their efforts in gathering the $\mathrm{CH}_{4}$ measurements and the GLOBALVIEW $\mathrm{CH}_{4}$ project for extending and integrating the data. We thank the GAGE and AGAGE networks for providing the MCF measurements used in this study.

Edited by: M. Heimann

\section{References}

Bekki, S. and Law, K. S.: Sensitivity of the atmospheric $\mathrm{CH}_{4}$ growth rate to global temperature changes observed from 1980 to 1992 , Tellus, 49B, 409-416, 1997.

Bekki, S. and Pyle, J. A.: A two-dimensional modeling study of the volcanic eruption of Mount Pinatubo, J. Geophys. Res., 99, 18861-18869, 1994.

Bekki, S., Law, K. S., and Pyle, J. A.: Effect of ozone depletion on atmospheric $\mathrm{CH}_{4}$ and $\mathrm{CO}$ concentrations, Nature, 371, 595-597, 1994.

Bender, F. A., Ekman, A. M. L., and Rodhe, H.: Response to the eruption of Mount Pinatubo in relation to climate sensitivity in the CMIP3 models, Clim. Dynam., 35, 875-886, doi:10.1007/s00382-010-0777-3, 2010.

Bousquet, P., Ciais, P., Miller, J. B., Dlugokencky, E. J., Hauglustaine, D. A., Prigent, C., Van der Werf, G. R., Peylin, P., Brunke, E.-G., Carouge, C., Langenfelds, R. L., Lathière, J., Papa, F., Ramonet, M., Schmidt, M., Steele, L. P., Tyler, S. C., and White, J.: Contribution of anthropogenic and natural sources to atmospheric methane variability, Nature, 443, 439443, doi:10.1038/nature05132, 2006.

Butler, T. M., Simmonds, I., and Rayner, P. J.: Mass balance inverse modelling of methane in the 1990s using a Chemistry Transport Model, Atmos. Chem. Phys., 4, 2561-2580, doi:10.5194/acp-42561-2004, 2004.

Camp, C. D., Roulston, M. S., Haldemann, A. F., and Yung, Y. L.: The sensitivity of tropospheric methane to the interannual variability in stratospheric ozone, Chemosphere - Global Change Sci., 3, 147-156, doi:10.1016/S1465-9972(00)00053-2, 2001.

Chipperfield, M. P., Randel, W. J., Bodeker, G. E., Dameris, M., Fioletov, V. E., Friedl, R. R., Harris, N. R. P., Logan, J. A., McPeters, R. D., Muthama, N. J., Peter, T., Shepherd, T. G., Shine, K. P., Solomon, S., Thomason, L. W., and Zawodny, J. M.: Global Ozone: Past and Future, in: Scientific Assessment of Ozone Depletion: 2002, Global Ozone Research and Monitoring Project, Report No. 47, chap. 4, Geneva, 2003.

Dee, D. P., Uppala, S. M., Simmons, A. J., Berrisford, P., Poli, P., Kobayashi, S., Andrae, U., Balmaseda, M. A., Balsamo, G., Bauer, P., Bechtold, P., Beljaars, A. C. M., Berg, L. V. D., Bidlot, J., Bormann, N., Delsol, C., Dragani, R., Fuentes, M., Geer, A. J., Haimberger, L., Healy, S. B., Hersbach, H., Holm, E. V., Isaksen, L., and Kallberg, P.: The ERA-Interim reanalysis : configuration and performance of the data assimilation system, Q. J. Roy. Meteorol. Soc., 137, 553-597, doi:10.1002/qj.828, 2011.

Dlugokencky, E. J., Masaire, K. A., Lang, P. M., Tans, P. P., Steele, L. P., and Nisbet, E. G.: A dramatic decrease in the growth rate of atmospheric methane in the northern hemisphere during 1992, Geophys. Res. Lett., 21, 45-48, 1994.

Dlugokencky, E. J., Dutton, E. G., Novelli, P. C., Tans, P. P., Masarie, K. A., Lantz, K. O., and Madronich, S.: Changes in $\mathrm{CH}_{4}$ and $\mathrm{CO}$ growth rates after the eruption of Mt. Pinatubo and their link with changes in tropical tropospheric UV flux, Geophys. Res. Lett., 23, 2761-2764, 1996.

Dlugokencky, E. J., Houweling, S., Bruhwiler, L., Masarie, K. A., Lang, P. M., Miller, J. B., and Tans, P. P.: Atmospheric methane levels off: Temporary pause or a new steady- state?, Geophys. Res. Lett., 30, 1992, doi:10.1029/2003GL018126, 2003.

Dlugokencky, E. J., Nisbet, E. G., Fisher, R., and Lowry, D.: Global atmospheric methane: budget, changes and dangers, Phil. Trans. 
R. Soc. A, 369, 2058-2072, doi:10.1098/rsta.2010.0341, 2011.

Dunfield, P., Knowles, R., Dumont, R., and Moore, T. R.: Methane production and consumption in temperate and subarctic peat soils: Response to temperature and $\mathrm{pH}$, Soil Biol. Biochem., 25, 321-326, 1993.

Elterman, L.: UV, Visible and IR Attenuation for Altitudes to 50 km, Environ. Res. Pap., 285, AFCRL-68-0153, 1968.

Etheridge, D. M., Steele, L. P., Francey, R. J., and Langenfelds, R. L.: Atmospheric methane between 1000 A. D. and present: Evidence of anthropogenic emissions and climatic variability, J. Geophys. Res., 103, 15979-15993, 1998.

European Commission and Joint Research Centre (JRC)/Netherlands Environmental Assessment Agency (PBL): Emission Database for Global Atmospheric Research (EDGAR), release version 4.1, available at: http://edgar.jrc.ec.europa.eu/ (last access: 17 November 2011), 2010.

Free, M. and Angell, J. K.: Effect of volcanoes on the vertical temperature profile in radiosonde data, J. Geophys. Res., 107, 4101, doi:10.1029/2001JD001128, 2002.

Fuglestvedt, J. S., Johnson, J. E., and Isaksen, I. S. A.: Effects of reductions in stratospheric ozone on tropospheric chemistry through changes in photolysis rates, Tellus, 46B, 172-192, 1994.

Gauci, V., Blake, S., Stevenson, D. S., and Highwood, E. J.: Halving of the northern wetland $\mathrm{CH}_{4}$ source by a large Icelandic volcanic eruption, J. Geophys. Res., 113, 1-8, doi:10.1029/2007JG000499, 2008.

Gettelman, A., Hoor, P., Pan, L. L., Randel, W. J., Hegglin, M. I., and Birner, T.: The extratropical upper troposphere and lower stratosphere, Rev. Geophys., 49, RG3003, doi:10.1029/2011RG000355, 2011.

GLOBALVIEW-CH4: Cooperative Atmospheric Data Integration Project - Methane. CD-ROM, NOAA ESRL, Boulder, Colorado, also available on Internet via anonymous FTP to ftp://ftp.cmdl. noaa.gov,Path:ccg/ch4/GLOBALVIEW (last access: 16 February 2012), 2009.

Grant, A., Archibald, A. T., Cooke, M. C., and Shallcross, D. E.: Modelling the oxidation of seventeen volatile organic compounds to track yields of $\mathrm{CO}$ and $\mathrm{CO}_{2}$, Atmos. Environ., 44, 3797-3804, doi:10.1016/j.atmosenv.2010.06.049, 2010.

Guenther, A. B., Zimmerman, P. R., Harley, P. C., Monson, R. K., and Fall, R.: Isoprene and Monoterpene Emission Rate Variability: Model Evaluations and Sensitivity Analyses, J. Geophys. Res., 98, 12609-12617, 1993.

Guo, S., Bluth, G. J. S., Rose, W. I., Watson, I. M., and Prata, A. J.: Re-evaluation of SO2 release of the 15 June 1991 Pinatubo eruption using ultraviolet and infrared satellite sensors, Geochem. Geophys. Geosyst., 5, Q04001, doi:10.1029/2003GC000654, 2004a.

Guo, S., Rose, W. I., Bluth, G. J. S., and Watson, I. M.: Particles in the great Pinatubo volcanic cloud of June 1991: The role of ice, Geochem. Geophys. Geosyst., 5, Q05003, doi:10.1029/2003GC000655, 2004b.

Hansen, J., Sato, M., Ruedy, R., Nazarenko, L., Lacis, A., Schmidt, G. A., Russell, G., Aleinov, I., Bauer, M., Bell, N., Cairns, B., Canuto, V., Chandler, M., Cheng, Y., Del Genio, A., Faluvegi, G., Fleming, E., Friend, A., Hall, T., Jackman, C., Kelley, M., Kiang, N., Koch, D., Lean, J., Lerner, J., Lo, K., Menon, S., Miller, R., Minnis, P., Novakov, T., Oinas, V., Perlwitz, J., Perlwitz, J., Rind, D., Romanou, A., Shindell, D., Stone, P., Sun, S.,
Tausnev, N., Thresher, D., Wielicki, B., Wong, T., Yao, M., and Zhang, S.: Efficacy of climate forcings, J. Geophys. Res., 110, D18104, doi:10.1029/2005JD005776, 2005.

Hansen, J., Ruedy, R., Sato, M., and Lo, K.: Global surface temperature change, Rev. Geophys., 48, RG4004, doi:10.1029/2010RG000345, 2010.

Hodson, E. L., Poulter, B., Zimmermann, N. E., Prigent, C., and Kaplan, J. O.: The El Niño Southern Oscillation and wetland methane interannual variability, Geophys. Res. Lett., 38, 3-6, doi:10.1029/2011GL046861, 2011.

Huijnen, V., Williams, J., van Weele, M., van Noije, T., Krol, M., Dentener, F., Segers, A., Houweling, S., Peters, W., de Laat, J., Boersma, F., Bergamaschi, P., van Velthoven, P., Le Sager, P., Eskes, H., Alkemade, F., Scheele, R., Nédélec, P., and Pätz, H.-W.: The global chemistry transport model TM5: description and evaluation of the tropospheric chemistry version 3.0, Geosci. Model Develop., 3, 445-473, doi:10.5194/gmd-3-445-2010, 2010.

Kinnison, D. E., Grant, K. E., Connell, P. S., Rotman, D. A., and Wuebbles, D. J.: The chemical and radiative effects of the Mount Pinatubo eruption, J. Geophys. Res., 99, 25,705-25,731, 1994.

Krol, M. and Lelieveld, J.: Can the variability in tropospheric $\mathrm{OH}$ be deduced from measurements of 1,1,1-trichloroethane (methyl chloroform)?, J. Geophys. Res., 108, 4125, doi:10.1029/2002JD002423, 2003.

Lowe, D. C., Manning, M. R., Brailsford, G. W., and Bromley, A. M.: The 1991-1992 atmospheric methane anomaly: Southern hemisphere $13 \mathrm{C}$ decrease and growth rate fluctuations, Geophys. Res. Lett., 24, 857-860, doi:10.1029/97GL00830, 1997.

Madronich, S.: UV radiation in the natural and perturbed atmosphere, in: Einvironmental effects of UV (Ultraviolet) radiation, edited by Tevini, M., 17-69, Lewis Publisher, Boca Raton, Fl, USA, 1993.

McCormick, M. P., Thomason, L. W., and Trepte, C. R.: Atmospheric effects of the Mt. Pinatubo eruption, Nature, 373, 399404, 1995.

Monteil, G., Houweling, S., Dlugockenky, E. J., Maenhout, G., Vaughn, B. H., White, J. W. C., and Rockmann, T.: Interpreting methane variations in the past two decades using measurements of $\mathrm{CH}_{4}$ mixing ratio and isotopic composition, Atmos. Chem. Phys., 11, 9141-9153, doi:10.5194/acp-11-9141-2011, 2011.

Montzka, S. A., Dlugokencky, E. J., and Butler, J. H.: NonCO2 greenhouse gases and climate change, Nature, 476, 43-50, doi:10.1038/nature10322, 2011a.

Montzka, S. A., Krol, M., Dlugokencky, E., Hall, B., Jockel, P., and Lelieveld, J.: Small Interannual Variability of Global Atmospheric Hydroxyl, Science, 331, 67-69, doi:10.1126/science.1197640, 2011b.

Niemeier, U., Timmreck, C., Graf, H.-F., Kinne, S., Rast, S., and Self, S.: Initial fate of fine ash and sulfur from large volcanic eruptions, Atmos. Chem. Phys., 9, 9043-9057, doi:10.5194/acp9-9043-2009, 2009.

Prather, M., Ehhalt, D., Dentener, F., Derwent, R., Dlugokencky, E., Holland, E., Isaksen, I. S. A., Katima, J., Kirchhoff, V., Matson, P., Midgley, P. M., and Wang, M.: Atmospheric Chemistry and Greenhouse Gases, in: Climate Change 2001: The Scientific Basis, Contribution of Working Group I to the Third Assessment Report of the Intergovernmental Panel on Climate Change, 239288, Cambridge Univ. Press, New York, USA, 2001. 
Prinn, R. G., Huang, J., Weiss, R. F., Cunnold, D. M., Fraser, P. J., Simmonds, P. G., McCulloch, A., Harth, C., Reimann, S., Salameh, P., O’Doherty, S., Wang, R. H. J., Porter, L. W., Miller, B. R., and Krummel, P. B.: Evidence for variability of atmospheric hydroxyl radicals over the past quarter century, Geophys. Res. Lett., 32, L07809, doi:10.1029/2004GL022228, 2005.

Quay, P., Stutsman, J., Wilbur, D., Snover, A., Dlugokencky, E., and Brown, T.: The isotopic composition of atmospheric methane, Global Biogeochem. Cy., 13, 445-461, doi:10.1029/1998GB900006, 1999.

Randel, J. W., Wu, F., Russell III, J., Waters, J., and Froidevaux, L.: Ozone and temperature changes in the stratosphere following the eruption of Mount Pinatubo, Geophys. Res. Lett., 100, 1675316764, 1995.

Ringeval, B., de Noblet-Ducoudré, N., Ciais, P., Bousquet, P., Prigent, C., Papa, F., and Rossow, W. B.: An attempt to quantify the impact of changes in wetland extent on methane emissions on the seasonal and interannual time scales, Global Biogeochem. Cy., 24, GB2003, doi:10.1029/2008GB003354, 2010.

Russell, P. B., Livingston, J. M., Pueschel, R. F., Bauman, J. J., Pollack, J. B., Brooks, S. L., Hamill, P., Thomason, L. W., Stowe, L. L., Deshler, T., Dutton, E. G., and Bergstrom, R. W.: Global to microscale evolution of the Pinatubo volcanic aerosol derived from diverse measurements and analyses, J. Geophys. Res., 101, 18745-18763, 1996.

Sander, S. P., Friedl, R. R., Barker, J. R., Golden, D. M., Kurylo, M. J., Wine, P. H., Abbatt, J. P. D., Burkholder, J. B., Kolb, C. E., Moortgat, G. K., Huie, R. E., and Orkin, V. L.: Chemical Kinetics and Photochemical Data for Use in Atmospheric Studies, Tech. Rep. 17, Jet Propulsation Laboratory, NASA, Pasadena, California, USA, 2011.

Schauffler, S. M. and Daniel, J. S.: On the effects of stratospheric circulation changes on trace gas trends, J. Geophys. Res., 99, 25747-25754, 1994.

Shindell, D. T., Faluvegi, G., Stevenson, D. S., Krol, M. C., Emmons, L. K., Lamarque, J.-F., Pétron, G., Dentener, F. J., Ellingsen, K., Schultz, M. G., Wild, O., Amann, M., Atherton, C. S., Bergmann, D. J., Bey, I., Butler, T., Cofala, J., Collins, W. J., Derwent, R. G., Doherty, R. M., Drevet, J., Eskes, H. J., Fiore, A. M., Gauss, M., Hauglustaine, D. A., Horowitz, L. W., Isaksen, I. S. A., Lawrence, M. G., Montanaro, V., Müller, J.-F., Pitari, G., Prather, M. J., Pyle, J. A., Rast, S., Rodriguez, J. M., Sanderson, M. G., Savage, N. H., Strahan, S. E., Sudo, K., Szopa, S., Unger, N., van Noije, T. P. C., and Zeng, G.: Multimodel simulations of carbon monoxide: Comparison with observations and projected near-future changes, J. Geophys. Res., 111, D19306, doi:10.1029/2006JD007100, 2006.

Soden, B. J., Wetherald, R. T., Stenchikov, G. L., and Robock, A.: Global Cooling After the Eruption of Mount Pinatubo: A Test of Climate Feedback by Water Vapor, Science, 296, doi:10.1126/science.296.5568.727, 2002.

Spahni, R., Wania, R., Neef, L., van Weele, M., Pison, I., Bousquet, P., Frankenberg, C., Foster, P. N., Joos, F., Prentice, I. C., and van Velthoven, P.: Constraining global methane emissions and uptake by ecosystems, Biogeosciences, 8, 1643-1665, doi:10.5194/bg8-1643-2011, 2011.

Stevenson, D. S., Dentener, F. J., Schultz, M. G., Ellingsen, K., van Noije, T. P. C., Wild, O., Zeng, G., Amann, M., Atherton, C. S., Bell, N., Bergmann, D. J., Bey, I., Butler, T., Co- fala, J., Collins, W. J., Derwent, R. G., Doherty, R. M., Drevet, J., Eskes, H. J., Fiore, A. M., Gauss, M., Hauglustaine, D. A., Horowitz, L. W., Isaksen, I. S. A., Krol, M. C., Lamarque, J.-F., Lawrence, M. G., Montanaro, V., Müller, J.-F., Pitari, G., Prather, M. J., Pyle, J. A., Rast, S., Rodriguez, J. M., Sanderson, M. G., Savage, N. H., Shindell, D. T., Strahan, S. E., Sudo, K., and Szopa, S.: Multimodel ensemble simulations of present-day and near-future tropospheric ozone, J. Geophys. Res., 111, D08301, doi:10.1029/2005JD006338, 2006.

Telford, P. J., Lathiere, J., Abraham, N. L., Archibald, A. T., Braesicke, P., Johnson, C. E., Morgenstern, O., O'Connor, F. M., Pike, R. C., Wild, O., Young, P. J., Hewitt, C. N., and Pyle, J.: Effects of climate-induced changes in isoprene emissions after the eruption of Mount Pinatubo, Atmos. Chem. Phys., 7117-7125, doi:10.5194/acp-10-7117-2010, 2010.

Thomason, L. W., Poole, L. R., and Deshler, T.: A Global Climatology Of Stratospheric Aerosol Surface Area Density As Deduced From Stratospheric Aerosol and Gas Experiment II measurements: 1984-1994, J. Geophys. Res., 102, 8967-8976, 1997.

Thoning, K. W. and Tans, P. P.: Atmospheric Carbon Dioxide at Mauna Loa Observatory 2. Analysis of the NOAA GMCC Data, 1974-1985, J. Geophys. Res., 94, 8549-8565, 1989.

Valentine, D. W., Holland, E. A., and Schimel, D. S.: Ecosystem and physiological controls over methane production in northern wetlands, J. Geophys. Res., 99, 1563-1571, doi:10.1029/93JD00391, 1994.

Van Aardenne, J. A., Dentener, F. J., Olivier, J. G. J., Klein Goldewijk, C. G. M., and Lelieveld, J.: A High Resolution Dataset of Historical Anthropogenic Trace Gas Emissions for the Period 1890-1990, Global Biogeochem. Cy., 15, 909-928, 2001.

Voulgarakis, A., Naik, V., Lamarque, J.-F., Shindell, D. T., Young, P. J., Prather, M. J., Wild, O., Field, R. D., Bergmann, D., Cameron-Smith, P., Cionni, I., Collins, W. J., Dalsø ren, S. B., Doherty, R. M., Eyring, V., Faluvegi, G., Folberth, G. A., Horowitz, L. W., Josse, B., McKenzie, I. A., Nagashima, T., Plummer, D. A., Righi, M., Rumbold, S. T., Stevenson, D. S., Strode, S. a., Sudo, K., Szopa, S., and Zeng, G.: Analysis of present day and future $\mathrm{OH}$ and methane lifetime in the ACCMIP simulations, Atmos. Chem. Phys. Discuss., 12, 22945-23005, doi:10.5194/acpd-12-22945-2012, 2012.

Wang, J. S., Logan, J. A., Mcelroy, M. B., Duncan, B. N., Megretskaia, I. A., and Yantosca, R. M.: A 3-D model analysis of the slowdown and interannual variability in the methane growth rate from 1988 to 1997, Global Biogeochem. Cy., 18, GB3011, doi:10.1029/2003GB002180, 2004.

Wang, Y. and Jacob, D. J.: Anthropogenic forcing on tropospheric ozone and $\mathrm{OH}$ since preindustrial times, J. Geophys. Res., 103, 31123-31135, 1998.

Williams, J. E., Strunk, A., Huijnen, V., and van Weele, M.: The application of the Modified Band Approach for the calculation of on-line photodissociation rate constants in TM5: implications for oxidative capacity, Geosci. Model Develop., 5, 15-35, doi:10.5194/gmd-5-15-2012, 2012.

Wilton, D. J., Hewitt, C. N., and Beerling, D. J.: Simulated effects of changes in direct and diffuse radiation on canopy scale isoprene emissions from vegetation following volcanic eruptions, Atmos. Chem. Phys., 11, 11723-11731, doi:10.5194/acp11-11723-2011, 2011. 